\title{
IMPACT OF FUEL ABUSES ON THE ECONOMIC SITUATION OF TRANSPORT COMPANIES
}

\author{
Daniela Todorova \\ “Todor Kableshkov" University of Transport, Sofia, Bulgaria
}

\section{() MESTE NGO}

JEL category: H12, Q4

\begin{abstract}
The specific nature of the transport process requires use of significant amount of current assets - fuels, lubricants, spare parts, etc., which have substantial value. Cost management requires proper costs determination, monitoring and control. The fuel abuse is one of the greatest problems in the transport companies. Almost every manager has faced this problem and adopted different anti-abuse measures accordingly. In value terms the expenditures in the transport company are the total amount of the inputs and the paid remuneration. The transport company management awareness of the mechanism of using current tangible assets plays a key role in reducing the production costs and lowering the cost price of the transport service. A particular important element in reducing prime cost is the availability of complete and reliable information about the fleet, routes of running, actual fuel consumption, etc. The information given by drivers, supervisors and mechanics is often contradictive and inadequate but it is not possible to make proper management decisions without objective information. Therefore, one of the priorities of the company management is to find the volume of actual fuel consumption and misuse of fuel. The paper discusses different approaches influencing the control of fuel consumption. Reducing fuel abuse is one of the options to reduce expenditures and cost price of the transport companies. The cost price of transport significantly affects the amount of the profit and profitability of the transport company.
\end{abstract}

Keywords: transport companies, control of fuel consumption, cost price

\section{INTRODUCTION}

Every day companies operating in market economy have to solve problems related to their survival and development. In that regard, each company analyzes its activity to evaluate its efficiency and competitiveness by applying certain

The address of the author:

Daniela Todorova

莑: daniela_dt@abv.bg revenue-increasing and expenditure-decreasing measures.

On one hand, the total company's costs determine the type, statute, size and structure of the company, and on the other hand, they depend on the different conditions and modes of transportation. The relations with customers are also of certain importance for the amount and structure of costs as customers determine the main requirements in terms of shipments. 
These main groups of factors interact and influence on the costs of transport companies. (Fig. 1.)

Cost management includes three main stages:

- determination of actual costs;

- cost analysis;

- planning and control of costs.

A prerequisite of the implementation of these stages in practice is the use of a cost classification that should meet the following requirements:
- to be in compliance with the existing regulations of accounting;

- to be in compliance with the particular accounting reports and documents of the transport enterprise;

- to enable a comparison with the costs of other enterprises with the same or other activity;

- to reflect the peculiarities of the activities of transport companies;

- to allow the application of uniform methods of determining the costs and prime cost of shipments

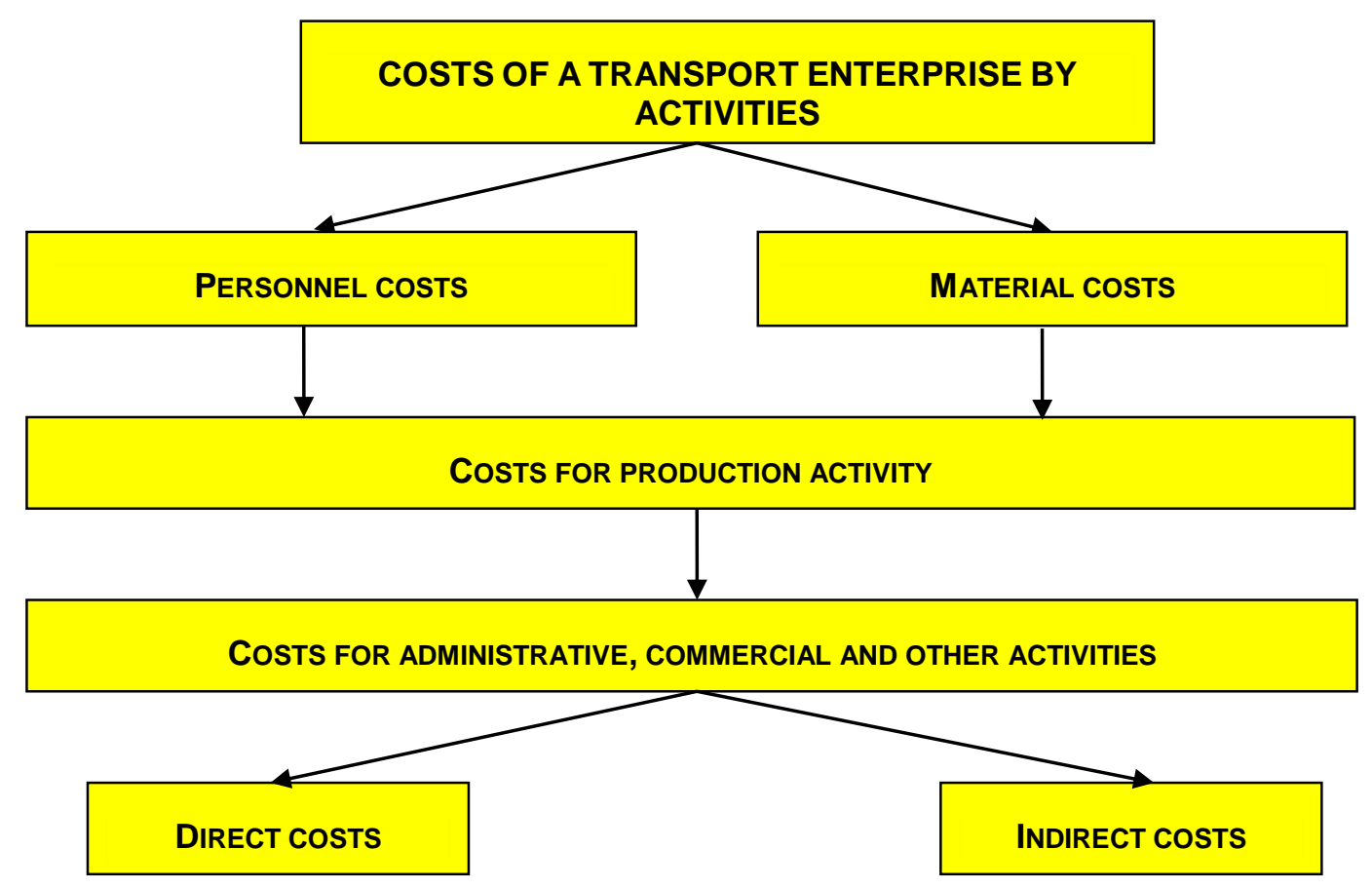

Fig. 1 Groups of factors interact and influence on the costs of transport companies

The specific nature of the transport process requires use of significant amount of current assets - fuels, lubricants, spare parts, etc., which have substantial value.

The fuel abuse is one of the greatest problems in the transport companies. Almost every manager has faced this problem and adopted different antiabuse measures accordingly. In value terms the expenditures in the transport company are the total amount of the inputs and the paid remuneration.

Experience has shown that only the overrun fuel is registered in travel sheets and books. If there is fuel saving, it is not registered and is misappropriated by the driver or petrol station operator.

Besides the factors enumerated above, the fuel costs depend on the prices it is bought at. The companies that have bigger vehicle fleet could reduce the fuel costs, which have a considerable share in shipment prime cost, by building their own petrol stations.

The delivery of fuel directly from producers' warehouses could reduce the price by about $30 \%$. With filling from own petrol stations, it is easier also to control the quality of fuels that directly influenced on the fuel consumption and indirectly on other costs of the carrier occurring with the use of low-quality fuels (spare parts, repairs, costs for stay due to damages, etc.). 
Fuel costs often could be lower than the calculated normative consumption due to the following reasons:

- the basic fuel consumption standard per a distance of $100 \mathrm{~km}$ has been calculated with a certain reserve;

- vehicles are driven under conditions that are more favorable than those used to calculate the correcting coefficients for specific operational conditions: driving on warm days; driving in regions of in big cities where there is no heavy traffic; transportation of light cargo; driving without air conditioning, etc.;

- influence of subjective factors: drivers of different experience, psychological environment in the team; personal problems of drivers, relations with other participants in traffic, etc. (Jelezov \& Todorova, 2010)

The human factor is of great significance to reduce fuel costs: the efficiency of work in a company depends much on vehicle drivers, supervisors and maintenance mechanics.

A particular important element in reducing prime cost is the availability of complete and reliable information about the fleet, routes of running, actual fuel consumption, etc.



Fig. 2. The costs and prime cost in transport companies

The information given by drivers, supervisors and mechanics is often contradictive and inadequate but it is not possible to make proper management decisions without objective information.
To carry out an adequate market policy, including prices, it is necessary to determine the costs and prime cost in transport companies in three aspects Fig. 2.

Before beginning the cost calculations for a certain shipment, it is necessary to establish the particular conditions, which it will be implemented under, and to ensure information that will be used for the quantitative assessment of factors influencing on these costs. It is necessary to have information about the route of shipment and the main technical and economic features of vehicles used.

The charges paid with shipment are directly dependent on the particular route.

The methods of determination and payment as well as the amount of charges vary by country and depend on the mode of transport, the type of vehicle, the type of freight, the crew's qualification and experience. The time of traveling depends on the conditions of shipment along a particular route. The time is determined by:

- distance;

- road conditions;

- stays at borders;

- places of loading and unloading;

- the time for the rest of crews, etc.

With determining the distance, the quantities of loaded and empty mileage should be considered as well.

The increase of the transport service efficiency without increasing the prime cost could be achieved by saving and rational use of raw materials, consumables and energy.

The costs of material and tangible nature present a big share, over $80 \%$, in the prime cost of shipments. It is why the savings of these costs affects prime cost to a greater extent than the savings of salary costs.

To retain the prime cost of transport services unchanged is possible not only by the relative reduction of material costs (for fuel, tires, energy per a unit of transport production), but also by the absolute reduction of these costs, i.e. by reducing technical standards.

For instance, the improvement of mileage coefficient reduces the relative share of costs of fuel and tires in the prime cost per $100 \mathrm{~km}$ of mileage but if fuel savings at $100 \mathrm{~km}$ of mileage 
and tire durability are increased, the prime cost will be reduced.
To save material, fuel, tires and energy, most of reserves could contribute Fig. 3 .

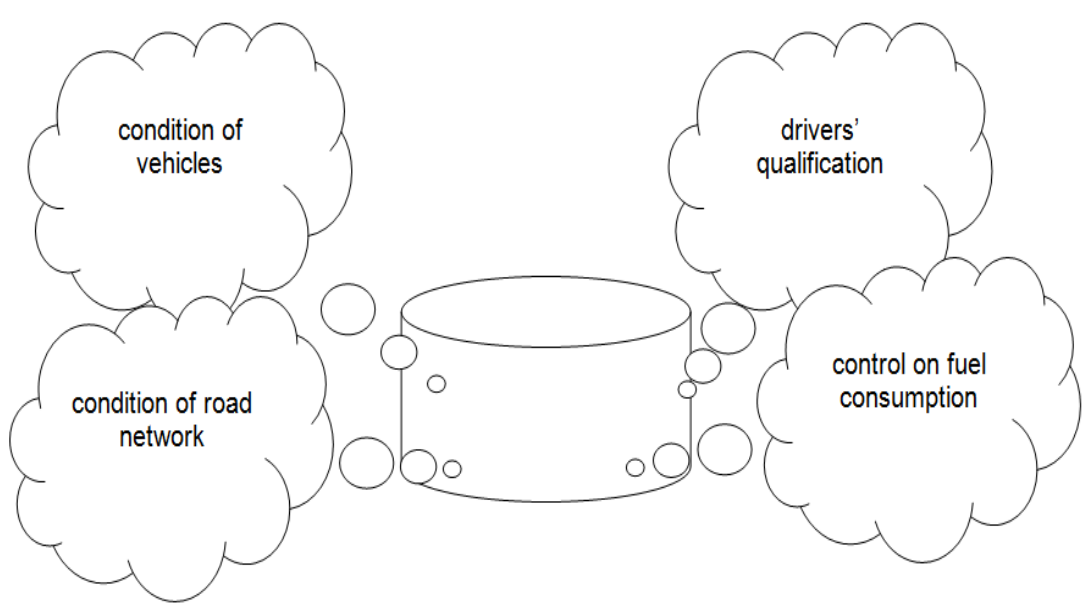

Fig. 3. Reserves

Management of expenditure is associated with application of management functions (planning, organizing, directing and controlling) in terms of organization's expenditure. In particular, the management of expenditure is accounting and forecasting where, when and in what volumes the organization's resources are used. (Lambovska, 2011)

The transport company management awareness of the mechanism of using current tangible assets plays a key role in reducing the production costs and lowering the cost price of the transport service.

The fuel consumption rate and its marginal value are regulated under specific Regulation of normalization of fuel and lubricants for cars and motorcycles. (Ministr na transport, 1989)

The Regulation defines the fuel consumption rate, which depends on the mileage and operating conditions of cars. The fuel consumption rate per $100 \mathrm{~km}$ is formed by a basic rate and additional adjustments for specific operating conditions.

The incorrect accounting of the fuel consumed by the drivers cause extensive damage to the company whose activity is mostly associated with transport services provision.

Therefore, one of the priorities of the company management is to find the volume of actual fuel consumption and misuse of fuel. For that reason, it is necessary periodic checks to be carried out.

\section{WAYS OF REDUCING MISUSE}

There are a number of ways that can be used by the managers to limit the incorrect accounting of the fuel consumed and misappropriation of the generated savings. The most important one is strengthening the control on using and accounting of material resources by carrying out preliminary, ongoing and subsequent control.

The method of sanctions and incentives is of key importance. By its rational use and application real savings in fuel consumption are achieved.

The latest technologies have a significant impact on the search for solutions for reducing misuse of fuel. For instance, the usage of cars with on-board computer for monitoring all parameters - elapsed mileage, average speed, fuel consumption, etc. allows the total control of expenditures.

Besides the enhanced control by officials, another way of reducing misuse of fuel and respectively monitoring of fuel consumption is the usage of latest information technologies and more specifically devices based on technology for global positioning.

Especially in companies owning and using more cars, the exactness of their location and the route and fuel consumption they had is of key importance.

The use of the GPS System allows an accurate and timely control of the company fleet to be carried out. 
By applying the method of management and control of the road transport a solution of the following problems is found: the number of the kilometers travelled, what was the maximum speed of driving, was the client visited on time and how much time was spend with him/her, how much fuel was loaded, how much fuel was consumed, etc.

This in turn allows analyzing and optimizing the work, as well as guaranteeing efficiency in the management.

Reducing the misuse of fuel and the cost price of the transport services offered by the transport companies may be done by applying the system of global positioning in the following trends:

Fuel Monitoring System (FMS) - it is an option for monitoring the main parameters of the vehicle used by using devices. Fuel consumption, distance travelled and speed of movement are a subject of basic monitoring.

The FMS System allows obtaining actual information about the real fuel consumption of the vehicle, as ultimate discipline of the driver of the vehicle is achieved. When applying the system the driver is not able to take advantage of false documents for fuel uplift.

The savings generated from the use of FMS System allow the company profit to be increased as the cost price of the transport is significantly reduced.

FMS System with sensor for fuel level; This system obtain actual and precise information from own digital sensors about the level of the fuel in the tank and makes real-time records of the speed, distance travelled, time of stopping and idle time (or working moto-hours).
The advantages of the system are: it records precise and complete information about the condition of the vehicle and it is protected from misuse and manipulation - independent power supply of the recording microprocessor device and digital sensor of the fuel tank.

This type of system registers the amount and time of refueling and defueling. The system can operate in all weather conditions.

Tire Pressure Monitor System (TPMS) This system is important because the reduction of tire pressure increases fuel consumption by about $3 \%$.

The limitation of expenditures will enable the company to increase the quality of the transport service and to improve the customer service. (CAST Engineering, 2014)

\section{CONCLUSION}

The reaction against thefts is a key element in company policy. Almost every day thefts of resources are found, as the effects of this violation are serious financial resources that have a negative impact on the expenditures of the transport companies.

The practice shows that the way of using and accounting fuels allows their inefficient use and is prerequisite for misuse. If the managers of the companies do not pay attention to this problem, it will definitely bear losses for them and for society as a whole.

To counteract and restrict legal offences it is necessary to apply the whole range of legal, economic, social and preventive measures, as well as to conduct adequate and timely control policy for restricting the possibilities of drivers' misuses.

\section{Works Cited}

CAST Engineering. (11 112014 r.). Danni za GPS i sistemata za upravlenie na transporta i control na razhoda na gorivo, bazirana na GPS tehnologiata. Извлечено от CAST Engineering Ltd.: http://cast-bg.net/bg/1464

Jelezov, E., \& Todorova, D. (2010). Rakovodstvo po cenoobrazuvane na transportnata usluga. Sofia: VTU "Todor Kableshkov".

Lambovska, M. (2011). Upravlenie na razhodite na organizaciata. Gabrovo: Eks-Pres.

Ministr na transport. (1989). Naredba № 3/25.09.1989 za normirane razhoda na goriva i smazochni materiali na avtomobilite i motocikletite. DV - State Gazette(93), 4. 
Received for publication:

19.11.2014

Accepted for publication:

20.12.2014

\section{How to cite this article?}

Style - APA Sixth Edition:

Todorova, D. (2015, Jan 15). Impact of fuel abuses on the economic situation of transport companies.

(Z. Čekerevac, Ed.) FBIM Transactions, 3(1), 1-6. doi:10.12709/fbim.03.03.01.01

Style - Chicago Sixteenth Edition:

Todorova, Daniela. 2015. "Impact of fuel abuses on the economic situation of transport companies." Edited by Zoran Čekerevac. FBIM Transactions (MESTE) 3 (1): 1-6. doi:10.12709/fbim.03.03.01.01.

Style - GOST Name Sort:

Todorova Daniela Impact of fuel abuses on the economic situation of transport companies [Journal] // FBIM Transactions / ed. Čekerevac Zoran. - Belgrade : MESTE, Jan 15, 2015. - 1 : Vol. 3. - pp. 1-6.

Style - Harvard Anglia:

Todorova, D., 2015. Impact of fuel abuses on the economic situation of transport companies. FBIM Transactions, 15 Jan, 3(1), pp. 1-6

Style - ISO 690 Numerical Reference:

Impact of fuel abuses on the economic situation of transport companies. Todorova, Daniela. 2015. [ed.] Zoran Čekerevac. 1, Belgrade : MESTE, Jan 15, 2015, FBIM Transactions, Vol. 3, pp. 1-6. 